\title{
Study on Strategies to Translate Mo Yan's Novels from the Perspective of Eco-Translatology
}

\author{
Luo Guotai
}

(NanChang Institute of Technology, Nanchang, 330099)

\author{
Keywords: Novels of Mo Yan; Eco-Translation; Strategy Research
}

\begin{abstract}
Eco-translation is to select translation works based on the original ecological structure of the original text, and to reproduce the original ecological structure in another language. As more and morepeople in the translation community at home and abroad began to pay attention to eco-translatology, some of them began to study on its application. Researches cover ecological environment of different translation domains, such as slogans, public languages, etc. This article will mainly discuss about the general situation of eco-translatology. According to the problems and deficiencies in the translation of Mo Yan's novels, it proposes a translation strategy for college English.
\end{abstract}

\section{Introduction}

With the development of the times and the progress of society, eco-translatology as a new theory of translation has received soaring attention and recognition from more and more translators. Eco-translatology is a new translation theory based on the philosophy of the East and the use of Eastern wisdom in the development of the original translation theory. This theory draws on Darwin's theory of "Survival of the Fittest", combining ecology with translation studies, adapted to the development requirements of the times.This theory provides a brand-new, harmonious, multi-dimensional perspective and new research paradigm and guide translation behavior based on novel theories. Therefore, this paper mainly introduces the background and basic connotation of eco-translatology, and uses the English translation of Mo Yan's fiction works as an example to analyze the main translation strategies used in the English translation with the aim of providing some references for translation practice. On the basis of further understanding of the fundamental concept of the eco-translatology, the thesis aims to strengthen and improve the applicable ability of translation skills and improve translation abilities in a comprehensive way by using corresponding translation strategies.

\section{Introduction of Mo Yan and His Major Works}

Mo Yan, formerly known as Guan Moye is from GaomiShandong, and is a famous Chinese contemporary writer. With the rise of a series of local works in the 1980s, its literary creation has had a significant impact on the literary world of China and the world as large, and has made outstanding contributions to the development of Chinese literature and world literature. In 2011, he won the Mao Dun Literary Prize; In 2012, he won the Nobel Prize and became the first Chinese writer to win the Nobel Prize in Literature. A glittering array of his works have become milestones in the Chinese literary world and have also received attention from readers of countries throughout the world. For this reason, more and more domestic and foreign experts, scholars, and translators have also carried out research on Mo Yan's works in all directions and from various angles.

Since 1981, Mo Yan began his literary career. He has 11 full-length novels, 25 medium-length novels, and 75 short stories. Among these outstanding works, there are more representative examples of "Red Sorghum", "Sandalwood Penalty", "Big Breasts and Wide Hips", " Life and Death Are Wearing Me Out", "Frog" and "The Republic Wine". His works embody profound ecological thoughts and are full of the complex emotions of "nostalgia". Therefore, Mo Yan is also categorized as a "root-seeking literature" writer. The ecological and cultural values demonstrated in 
his works have increasingly attracted people's attention as they pay more and more attention to ecological civilization and ecological harmony.

\section{The Background of the Development of Eco-Translatology Studies}

The birth of eco-translatology is the result and product of a combination of factors. First of all, it is the result of social civilization transformation. Since the 1960s, human society has gradually begun to transform from industrial civilization to ecological civilization. More and more regions and countries have begun to pay attention to ecological issues and are paying more and more attention to environmental integrity and developmental relationships. The scientific concept of development and the principle of sustainable development have also been increasingly accepted. Under this circumstance, the "ecological" dimension is increasingly being introduced into the field of social science research, including translation studies.

Second, the emergence of eco-translatology is the inevitable result of the transformation of modern philosophy. Since the 20th century, the transition from the Subject/object dichotomy to the intersubjectivity and from the center to the overall concept has gradually occurred in the ideological and philosophical fields. Starting from1960s, the French philosopher Jacques Derrida proposed the concept of "center" - he claims the center is both inside and outside the structure, "the center is not the center". In 1970s, Norwegian philosopher Arne Naess introduced the phrase "Deep Ecology" to environmental literature, which began to gradually introduce ecology intophilosophy and ethics, proposing ecological self, ecological equality, and ecological harmony. Later, the American philosopher David Griffin etc. developed this doctrine based on the previous efforts. It can thus be seen that what modern and contemporary philosophy is facing is an important shift from epistemology to the ontology, from the human-centered concept to the ecological overall concept. Due to the existence of this philosophical change, translation studies also tried to integrate the thinking of translation activities from the perspective of "translation ecology". The study of eco-translatology came into being.

\section{Analysis of Translation Strategies Application in English-Chinese Translation of Mo Yan's Novels from the Perspective of Eco-Translatology}

\section{Language Dimension Conversion}

In the perspective of eco-translatology, the "three-dimensional" transformation is the main method of translation. Among them, the transformation of language dimension is carried out in different aspects and at different levels, mainly referring to the translator's adaptive choice of language forms in the process of translation. The huge differences between English and Chinese in the form of language expressions determine their differences in language expression. Based on the ecological environment that is fluent in language, translators should make necessary choices and adjustments to the original language in terms of vocabulary, thus transforming the language form. As far as the linguistic features of Chinese and English are concerned, English emphasizes a form of congruence and Chinese emphasizes parataxis. English uses many conjunctions and prepositions, but the omission in Chinese is more common. Therefore, in the process of translation, the translator should fully recognize this and grasp the language features of the translated language so as to better handle the text translation. In the process of translating Mo Yan's novels, there are many manifestations of this strategy.

\section{Cultural Dimension Transformation}

The transformation in this dimension focuses on the translator's translation process and pays more attention to the connotation of bilingual culture and the cultural interpretation behind the text. While translating, it is not only necessary to focus on the transformation of the target language and the source language, but also to understand and grasp the entire cultural system. In Mo Yan's novels, there are a lot of local features demonstrating the personalities of laboring people.This is particularly prominent in the depiction of characters, especially language descriptions. Therefore, in the process of translation, it is necessary to take into account the differences in language and culture 
between Chinese and English, the differences in cultural backgrounds, etc., and make adaptive choices and conversions in cultural dimensions, which is the connotation of eco-translatology. For example, there is a scenario in the novel describing the relevant conversations that started everyone's dissatisfaction with the tractor operator:

Du Qiumei spit at the tractor and blushed, walking to the side of her handcart. Lamei crouched softly: "Hell no! Pig,Shame on you." The cart-driverwas unpleasant and stepped forward yanking the driver's neck collar hard and shouted, shouting: "Hey, man! You should be ashamed."

\section{Communicative Dimension Transformation}

According to the related theories of eco-translatology, the adaptive selection and transformation in the communication dimension refers to the translator's intention to implement bilingual communication in the translation process. From a theoretical perspective, the transformation of this dimension is the result of the further deepening and development of the above two dimensional transformations. In the process of translation, translators are required not only to effectively communicate language information, but also to focus on the communicative purpose that translation can achieve. In view of this, in the process of translation, the translator must not only ensure the selection and transformation of the relevance and adaptability of the hypotaxis and the paradigm in terms of language dimension and cultural dimension, but also pay attention to the adaptation, selection and transformation in the dimension of communication.

In the process of translating Mo Yan's novels into English, this translation strategy also has multiple applications. It is necessary to apply the communication of the text as an important principle of text translation and highlight some of the text's emphatic meanings. E.g:

"It is the beginning of the lunar calendar in early September. It is the standard autumn night in early September. At this time, the chilly autumn air was not so cold, but it was enough for everyone."

\section{Summary}

As a new translation theory, eco-translatology still has many deficiencies in its development. The connotation and denotation of this theory still have more room for development. This article comprehensively analyzes the English translation of the text of Mo Yan's novels, it is easy to find that there are still many deficiencies in the process of translating texts into English.

There are still many problems to be improved in the use of different translation strategies from the perspective of eco-translatology. The new theoretical perspective of eco-translatology puts forward new requirements for translation strategies, which needs to be deeply explored. From the perspective of ecotranslatology, it is an important issue that we pay attention to the proficiency and flexibility of translation theories and strategies to the translation of different texts and to strengthen and improve translation skills and levels. The theoretical perspectives and connotations of eco-translatology are perfected in the practice of translation and we should create harmony between the original copy and translated copy as well as the original author and translator while translating in the entire ecological environment.

\section{Acknowledgement}

Project Fund: Jiangxi University Humanities and Social Sciences Research Project(No.YY1431)

\section{References}

[1] Lian R, University T. On Translations of the Character"Dao"in Daodejing- From the Perspective of Eco-translatology[J]. Overseas English, 2016.

[2] Zhai M. Research on Teaching Mode of College English Translating Course from the Perspective of Eco-translatology[C]// International Conference on Social Science and Higher Education. 2017.

[3] Zuo J L, Zhao N, Department E, et al. Research on English Translation of the Public Signs 
Adopted in Shaanxi Hospitals from the Perspective of Eco-translatology[J]. Value Engineering, 2017.

[4] Zhang W. Study on the Development of English Translation of Chinese Classics from the Perspective of Eco-translatology[J]. 2017(icsste).

[5] Wang Z. A Research on Foreign-oriented Translation of A Bite of China from the Perspective of Eco-translatology[J]. Journal of Inner Mongolia Normal University, 2017.

[6] Li Q, Li P. Study on Documentary Subtitle Translation from the Perspective of Eco-Translatology_ A Case Study of English Version of CCTV4 Homeland Dreamland[J]. Journal of Shaoxing University, 2017.

[7] Gao L, Liu B. Construction of Translation Teaching Model from Perspective of Eco-translatology[J]. China Educational Technology \& Equipment, 2017.

[8] Xue J X, Kang B. A Study on Business Contract Translation from the Perspective of Three-Dimensional Transformation of Eco-Translatology[J]. 2017(icesd).

[9] Liu J, Song X, Liu X. An Analysis of Chinese-English Translation of Public Signs in Tourist Attractions from the Perspective of Eco-translatology__Evidence from Three Gardens in Xi'an Chan-ba Ecological District[J]. Guide of Science \& Education, 2017.

[10] Zhou T, Li C, Yao X. A Research on the Translation Strategies of The Analects from the Perspective of Eco-translatology-The English Translations by James Legge and $\mathrm{Ku}$ Hungming[J]. Journal of University of Shanghai for Science \& Technology, 2016.

[11] Chao L I. On Subtitle Translation of Game of Thrones from the Perspective of Eco-translatology[J]. Overseas English, 2017(8):131-133.

[12] Ma J. The English Translation of Public Signs in Qingdao-From the Perspective of Eco-translatology[J]. Theory \& Practice in Language Studies, 2014, 4(12). 